INDEPENDENT JOURNAL OF MANAGEMENT \& PRODUCTION (IJM\&P)

\title{
EMOTIONAL INTELLIGENCE AND ORGANIZATIONAL COMPETITIVENESS: MANAGEMENT MODEL APPROACH
}

\author{
John N. N. Ugoani \\ College of Management and Social Sciences, Rhema University, \\ Nigeria \\ E-mail:drjohnugoani@yahoo.com
}

Submission: 19/01/2016

Revision: 23/02/2016

Accept: 28/02/2016

\begin{abstract}
Modern organization theory considers emotional intelligence as the index of competencies that help organizations to develop a vision for competitiveness. It also allows organizational leaders to enthusiastically commit to the vision, and energize organizational members to achieve the vision. To maximize competiveness organizations use models to simplify and clarify thinking, to identify important aspects, to suggest explanations and to predict consequences, and explore other performance areas that would otherwise be hidden in an excess of words. The survey research design was used to explore the relationship between emotional intelligence and organizational competitiveness. The study found that emotional intelligence has strong positive relationship with organizational competitiveness.
\end{abstract}

Keywords: Hidden in excess of words, Psychometric tradition, Selfregulation, Self-motivation, Synergistic clusters, Emotional competence 


\section{INTRODUCTION}

An emotionally intelligent organization is the one that seeks to come to firm terms with any differences between the values it philosophies and those it lives. Certainty about organizational values, spirit, and mission leads to a decisive selfconfidence in corporate decision-making. An organizational mission statement is a statement of purpose that serves as a guide for strategy and decision making.

Such a statement serves an emotional function articulating the shared sense of goodness that allows the organization to feel that what it wants to do is worth while. Mission statements of organizations that survive competition often draw from the imperatives of emotional intelligence. Emotional intelligence refers to the capacity for recognizing our own feelings and those of others, for motivating ourselves and for managing emotions well in ourselves and in our relationships.

It describes abilities distinct from, but complementary to, academic intelligence, the purely cognitive capacities measured by intelligence quotient (IQ). A competitive organization is one that has the ability to satisfy stakeholders, customers, employees, and other needs of the environment. Competitiveness relates to how effective an organization meets these needs comparative to other similar organizations.

Competitiveness is based on strategy, a plan for achieving organizational goals, through tactics, or methods and actions taken to accomplish strategies. With an operation strategy, which involves the approach consistent with the organizational strategy, organizations seek to achieve their goals. Such actions are complemented by emotional intelligence that provides distinctive competencies, or the special attributes or abilities that give an organization a competitive edge.

This competitive edge allows that organization to distinguish between order qualifiers, which is the characteristics of what customers perceive as minimum standards of acceptability to be considered for patronage, order winners, which is related to an organizations goods or services that make it to be perceived as better than competitors. Competitive organizations are frequently productive organizations. Productivity is a measure of the effective use of organizational resources, usually expressed as the ratio of output to input (STEVENSON, 2002). 
DOI: 10.14807/ijmp.v7i3.427

Managers and workers are the people responsible for the management of other resources in an organization, and for them to perform well they require a good dose of emotional intelligence, Competitive organizations assess themselves in various ways not only through profit. Knowing how those shared values work amount to emotional self-awareness at the organizational level.

Just as each person has a profile of strengths and weaknesses in the different areas of competence so it is with organizations. For organizational competitiveness can be mapped at various levels through assessments or internal surveys and models. Models are important to gauge the pulse of an organization's viability.

According Goleman (1998) systems theory states that to ignore any significant category of data is to limit understanding and response. Sounding the depths of emotional currents in an organization can have concrete benefits. A model is an abstraction of reality, a simplified version of something that may lead to a better knowledge of reality.

Models are sometimes classified as physical, mathematical or schematic. Schematic models include graphs, charts, blueprints, pictures, drawings, etc. Managers frequently use schematic models to read organizational reality with the view of enhancing organizational competitiveness.

Cleary (1992) describes a model as a simplified representation of the real world. This suggests that it takes the form of a diagrammatic representation or may be conceptual. Irrespective of whether the model may be a diagram or be conceptual, the purpose of any model is to simplify and clarify thinking to identify important aspects, to suggest explanations, and to predict consequences (DYE, 1992).

Models have been widely employed in management theory to help clarify relationships and processes, including McGregor's (1960) theory ' $X$ ' and theory ' $Y$ ' model, Blake and Mouton's (1964) nine part grid diagram, and conceptual models developed by Maslow (1954) Herzberg (1974). These studies confirm that models assist the researcher to understand the "real" world and to provide a useful touchstone between the real world and the reality of the researcher.

A schematic model allows a link between theory and the real world. It is analogous to a map that links analysis and investigation with the world of observable 
DOI: 10.14807/ijmp.v7i3.427

events. The schematic model displays the relationships between variables. Keeves (1997) claims that schematic models are very popular in educational research and such symbolic and diagrammatic models help to make explicit the structure of a concept that would otherwise be hidden in an excess of words.

A major advantage of schematic models is that they are often relatively simple to construct, and change. More over, they have some degree of visual correspondence. Managers use schematic models in a variety of ways and for a variety of reasons. Schematic models are beneficial for organizational competitiveness because they are generally easy to use and less expensive than dealing directly with the actual situation.

Schematic models provide a systematic approach to problem-solving, and increase understanding of the problem. They serve as consistent tools for evaluation, and at the same-time, provide a standardized format for analyzing problems (MORECROFT; STARMAN, 1994; JAWORSKI, 1996). The issue of human skills has a rich history in management theory. Whereas scientific management theory emphasizes the technical and efficiency aspects of work, the human relations theory emphasizes the human element, and concludes that in addition to the technical aspects of work, employee motivation is critical for influencing productivity and overall organizational competitiveness.

This gave rise to many motivation theories including theory $Z$ which emphasizes that group motivation such as lifelong employment, employee problemsolving and consensus building are highly correlated to organizational competitiveness (STEVENSON, 2002; GERARD; TEURFS, 1995; FINEMAN, 1997; DRUCKER, 1998).

An organization is like an organism, with a moment of birth, growth through several distinct stages of development, maturation, and finally an end. However, the competitive ones last longer. And the ingredients of an effective and competitive organization include a healthy dose of emotional intelligence because there are numerous variables that can prove fatal to an organization. But a failure in emotional intelligence can be fatal to organizational competitiveness (ASTD, 1997; SPECTOR, 2005; KLUEMPER, 2008; PFEIFER, 2000; MCLEOD, 1997; SALONA; SLUYTER, 1997; SJOBERG, 2000; SAARNI, 1998; WU, et al., 2006; WEISS, 2000). 


\subsection{Statement of the problem}

For decades organizations rooted in the scientific management theory tend to emphasize the technical and efficiency aspects of work to the detriment of the human elements that are equally very critical for competitive advantage. Today the challenge of knowledge workers, demographic changes, diversity, among others, means that the premium on emotional intelligence will rise as organizations become increasingly dependent on the talents and creativity of workers who are independent agents.

According to Goleman (1998) 77 percent of American "knowledge workers" says they decide what to do on the job, rather then being told by someone else. The rising popularity of flextime is accelerating this trend. Autonomy can work only if it goes hand in hand with self-control, trustworthiness, and conscientiousness.

And as people work less for the organizations, and more for themselves, emotional intelligence will be required to maintain the relationships vital for workers' survival and organizational competiveness.

\subsection{Objective of the study.}

The study was designed to explore the degree of relationship between emotional intelligence and organizational competitiveness.

\subsection{Scope of the study}

The study was conducted within Abia State Nigeria. Abia State is one of the 36 states of Nigeria and with the size of 6,320 square kilometers, almost two times the size of Lagos State which is 3,577 square kilometers. Therefore study in Abia State provides a fine representation of a study in Nigeria.

\subsection{Significance of the study.}

The study provides insights on the importance of emotional intelligence in organizational competitiveness. This may help in policy formulation and execution. Undergraduate and graduate students of contemporary management theory, trainers and the general public will also learn more about the romance between emotional intelligence and organizational competitiveness. 
DOI: 10.14807/ijmp.v7i3.427

\subsection{Limitations of the study}

The study was constrained by finance, logistics and current literature. However, these critical constraints did not count against the academic value of this research.

\subsection{Hypotheses}

To guide the study toward achieving the objective, two hypotheses were formulated and tested at 0.05 level of significance.

- Ho: Emotional intelligence has no relationship with organizational competitiveness.

- Hi: Emotional intelligence has a relationship with organizational competitiveness.

\section{LITERATURE REVIEW}

In attempts to enhance career success and enhance organizational effectiveness and competitiveness, psychologists make a distinction among types of intelligences like practical intelligence and emotional intelligence.

According to Sternberg (1996) practical intelligence is intelligence related to overall success in living. Noting that traditional tests were designed to relate to academic success he points to evidence showing that intelligence quotient (IQ) does not relate particularly well to career success.

Sternberg (1996) argues that career success requires a very different type of intelligence. Therefore, the concept of practical intelligence is broadened even further beyond the intellectual realm to involve and consider intelligence involving emotions. Emotional intelligence is the set of skills that underlie the accurate assessment, evaluation, expression, and regulation of emotions (GOLEMAN, 1995).

Abilities in emotional intelligence might help explain why people with only modest IQ can be quite successful, despite the lack of traditional intelligence. The notion of emotional intelligence teaches that there are many ways to demonstrate intelligent behavior, just as there are multiple views of the nature of intelligence. At the present time, three main models of emotional intelligence exist. 
DOI: 10.14807/ijmp.v7i3.427

The first model by Salovey and Mayer (1990) perceives emotional intelligence as a form of pure intelligence, emphasizing that emotional intelligence is a cognitive ability. A second model by Bar-On (1997) regards emotional intelligence as a mixed intelligence consisting of cognitive ability and personality aspects. This model emphasizes how cognitive and personality factors influence general well-being.

The third model introduced by Goleman (1995) also perceives emotional intelligence as a mixed intelligence involving cognitive ability and personality aspects. However, unlike the model purposed by Bar-On (1997) Goleman's (1995) model focuses on how cognitive and personality factors determine organizational effectiveness and competitiveness.

Emotional intelligence research finds significant relationships among all the three models of emotional intelligence, by recognizing the co-dependence of both the cognitive and the noncognitive factors. This suggests that emotional intelligence draws upon a psychometric tradition, by relating to the measurement of mental data, and that intelligence must meet three criterions to be defined as such.

This implies that emotional intelligence must be conceptual, in which case, it must reflect mental aptitudes rather than behaviours, it must be correlational by sharing similarities with and yet remain distinct from any other types of intelligences, and it must be developmental, as it must increase with an individual's experience and age. This psychometric tradition entails that emotional intelligence comprises of a discrete set of abilities that integrate affective and cognitive skills (PETRIDES; FURNHAM, 2001; MIKOLAJEZAK, et al., 2007; BAR-ON, 2004).

These skills are the competence needed by people to perform well in organizations, and an emotional competence is a learned ability based on emotional intelligence. Emotional competencies determine the potential for learning the practical skills that are based on emotional intelligence. Emotional competence shows how much of the potential the individual can translate into on-the-job capabilities.

For example, being good at serving customers is an emotional competence based on empathy. Likewise, trustworthiness is a competence based on selfregulation or handling impulses and emotions well. Both empathy and trustworthiness are competencies that can make people outstanding in their work. 
DOI: 10.14807/ijmp.v7i3.427

According to McClelland (1993) competence comes in multiples. Organizations and individuals interface in ways that require a multitude of emotional intelligence abilities, each most effective when used in conjunction with others in synergistic clusters. Clusters are behavioural groups of the desired competencies. They are often linked conceptually or schematically and defined by a theory as a convenient operationlization and understanding of which competencies are associated with others. This provides parsimony for organizational competitiveness.

\subsection{Imperatives of Emotional Intelligence and Organizational competitiveness.}

Organizations are formed to pursue goals that are achieved more competitively by concerted efforts of a group of people than by individuals working alone. Organizations are devoted to producing goods and services or providing services. They may be for profit or non profit organizations. Their goals, products and services may be similar or quite different.

Nevertheless, their functions and the way they operate are similar. Strategy and productivity among other factors are critical to organizational competitiveness. Strategy relates to the plans that determine the directions an organization takes in providing goods, and productivity on the other hand is the effective use of organizational resources.

Organizations must be competitive enough to be able to sell their goods and services in the marketplace. They compete with one another in various ways. These include price, product or service quality, level of flexibility, and quality of manpower. To be significantly competitive, an organization requires managers and workers who have the appropriate skills and appetite to perform their jobs well.

This is imperative because managers and workers are the people at the heart and soul of an organization and if they are competent and motivated they can provide a distinctive competitive edge by their skills and the ideas they create. Emotional intelligence is the index of competencies that help organizations achieve effectiveness and competitiveness. 
DOI: 10.14807/ijmp.v7i3.427

\subsection{Management model approach.}

Some people seem to read best, think best, or understand best, when concepts are clearly expressed quantitatively, or in a model form. The idea is that one model is worth a thousand words. To the management scholar, the importance of the use of models and other quantitative techniques is the recognition of the impact of these new approaches in the management process (GEORGE, JR. 1972).

Cherniss (2001) illustrates the potency of emotional intelligence and organizational effectiveness through his model of emotional intelligence and organizational effectiveness. Cherniss (2001) believes that emotional intelligence components like leadership, organizational climate and culture, individual emotional intelligence, group emotional intelligence, other human resource functions, result to relationships that give rise to organizational effectiveness.

Human resource functions like training and development are important to motivate employees toward contributing to organizational competitiveness. No single model is complete in itself, and this model captures some but not all the important competencies that contribute to the development of individual and group emotional intelligence in organizations necessary for building organizational competitiveness.

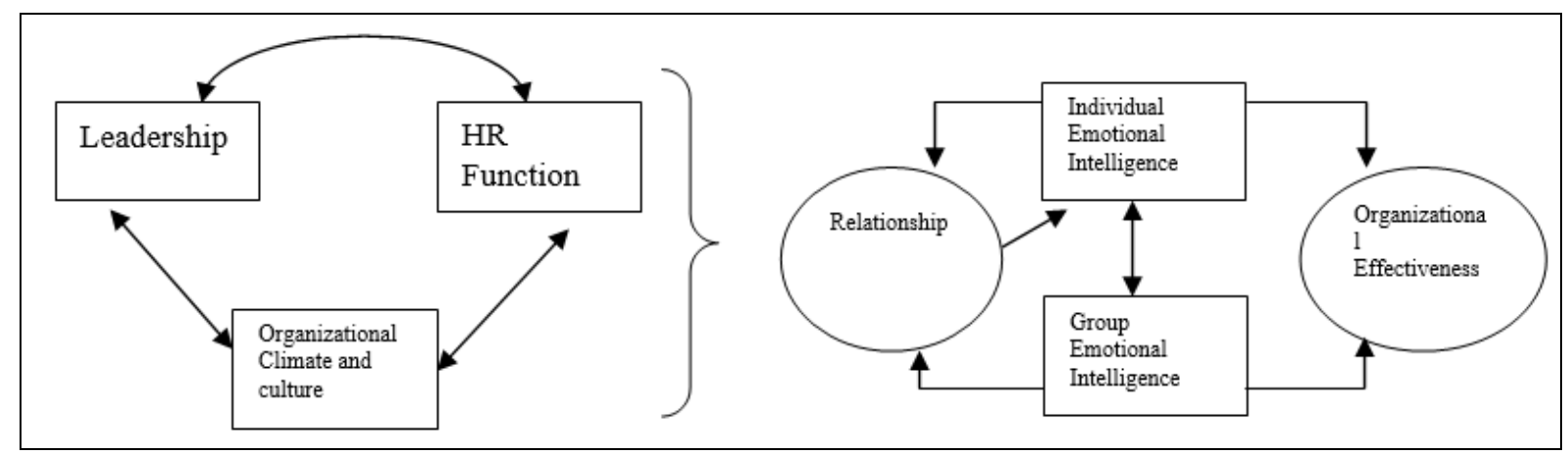

Figure 1: Leadership and organizational effectiveness.

Source: Cherniss \& Goleman (2001) The Emotionally Intelligent Workplace.

The model typically shows that the emotional intelligence of the mentor, boss, or peer will influence the potential of a relationship with that person for helping organizational members develop and use talent that is crucial for organizational effectiveness. It also implies that people who are members of emotionally intelligent groups become more emotionally intelligent individuals.

The model suggests that ultimately any attempts to improve emotional intelligence in organizations will depend on relationships. Even training interceptions 
DOI: 10.14807/ijmp.v7i3.427

or human resource policies will affect emotional intelligence through their effect on relationships among individuals and groups in the organization.

According to Cherniss and Goleman (2001) a Gallup Organization study of two million employees at seven hundred companies found that how long an employee stays at a company and how productive the person is there is determined by his or her relationship with her immediate supervisor. They state that the most effective bosses are those who have the ability to sense how their employees feel about their work situation and to intervene effectively when those employees begin to feel discouraged or dissatisfied.

Effective bosses are also able to manage their own emotions, with the result that employees trust them and feel good about working with them. Organizations face intense needs today, both public sector and private. And in virtually every case, emotional intelligence must play an important role in satisfying the needs. For instance, coping with massive change involves among other things, the ability to perceive and understand the emotional impact of change on ourselves and others.

To be effective in helping their organizations manage change, managers first need to be aware of and to manage their own feelings of anxiety and uncertainty. Then they need to be aware of the emotional reactions of other organizational members and act to help people cope with those reactions. At the same time in this process of coping effectively with massive change other members of the organization need to be actively involved in monitoring and managing their emotional reactions and those of others.

Cherniss (2001) in his model suggests that organizational effectiveness is a manifestation of workplace success and both are essential for organizational competitiveness. The contemporary organization faces unprecedented environmental and technological change. To be competitive, one of the biggest challenges for organizations is to continuously change in a way that meets the demands of this turbulent competitive environment.

Organizational competitiveness embraces the concept of the learning organization. The learning organization can be defined as one in which all employees are involved in identifying and solving problems, which allows the organization to continually increase its ability to grow, learn and achieve its purpose. The organizing 
DOI: $10.14807 /$ ijmp.v7i3.427

principle of the learning organization is not effectiveness or efficiency but problem solving and competitiveness.

This can only be achieved through a team-based structure, empowered employees and information sharing processes. These components of organizational competitiveness among others can be expressed through business or schematic models so as to simplify or clarify thinking, to identify important aspects, and to predict possible consequences. Models are instrumental to making explicit structures and ideas necessary for organizational competitiveness that would otherwise be lost to mere imagination (SENGE, 1990).

Drucker (1998) deems models essential and asserts that most organizations move to correct the culture of the organization before they accurately establish the assumptions upon which the organization has been built. He emphasizes that these are the very assumptions that shape the organization's decision about what to do and what not to do. In other words, to successfully generate organizational competitiveness, it is important to establish correct assumptions about the organization and its environment.

They must also fit one another, be known, understood, and constantly tested throughout the organization. According to Spencer and Spencer (1993) emotional competencies are to a large extent applicable to top performance in virtually every job. One estimate is that generic competencies cover about 80 to 98 percent of behaviours typical of star performance, depending on the specific job.

The estimate includes three that are purely cognitive: analytical thinking, conceptual thinking, and job specific expertise and so do not fall among the emotional intelligence group. Organizations can establish core competencies required for their competitiveness through models such as Gap Analysis models among others. Gap analysis can be used to assess the organization's manpower quality relative to its expectations, customers, and rivals. Such results help in benchmarking for the desired levels of competitiveness (HAY/MCBER, 2000). 
DOI: 10.14807/ijmp.v7i3.427

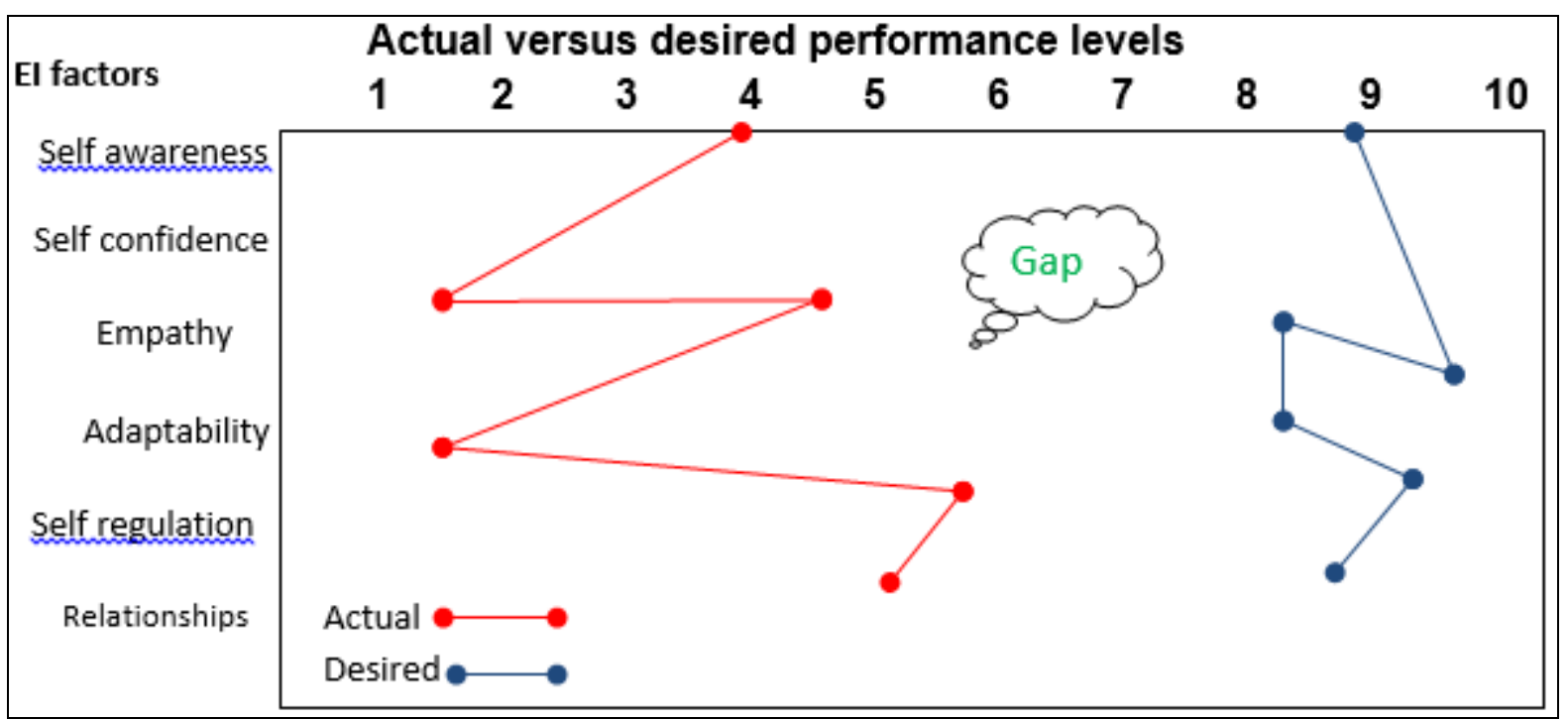

Figure 2: Gap analysis model of organizational competitiveness

Source: Ugoani, 2015.

Based on a scale of 1-10, Figure 2 suggests that an organisation can gauge the quality of its manpower on emotional intelligence and take necessary steps to fill any gaps needed for their competitiveness. Another good management model is the five forces model. This is one of the approaches to evaluating an organisation's competitive position in the light of the strucure of its industry.

The five forces are: buyer power, potential entrants, suppliers, substitute products, and industry rivals. The model is operationalized by the development of a list of factors that fit under each of the subheading, with a view to building competitive advantage.

All organisations find models very useful in matching competition in their respective areas of operations (CHASE, et al, 2001) Drucker (1998) puts emphasis on the assertion that it is vital to establish assumptions about the core competencies needed to establish organisations vision and mission. And this can be done through an analysis that warrants the measurement of actual and desired levels of performance to determine the competitiveness of the organisation vis-a-vis competition.

\section{METHODOLOGY}

\subsection{Research design}

The survey research design was employed for the study. Surveys are very useful in describing the features of a large population or a particular subset of the 
DOI: 10.14807/ijmp.v7i3.427

population such as the business community or the working class, or the unemployed. It is critical in intelligence and psychometric investigations. (NUNNALLY; BERNSTEIN, 1994)

\subsection{Population and sample}

The Target population comprised the people in Abia State Nigeria. Abia State is one of the 36 states in Nigeria; therefore, the population in Abia State is a good representation of the Nigerian population. The sample comprised of 352 participants (197 males and 155 females) ranging in age from 21 to 65 ( $M=43$ years; $S D=22$ ). This sample for the study was selected through the simple random sampling method, while the sample size was determined using the Yamane's technique.

\subsection{Sources of data}

Data for the study were collected through primary and secondary sources, such as questionnaire administration, interviews, books, journals, newspapers, etc. The mixed method was used so as to complement, supplement, and validate data through each other.

\subsection{Data collection instrument}

The instrument for data collection was based on the Schutte, et al (1998) scale. The Schutte Self-Report Emotional Intelligence (SSREI) scale is comprised of 33 5-point Likert scale items, three of which were negatively, keyed. Previous investigations have found the total score of the SSREI scale to be acceptably internally consistent and with Cronbach's Alpha reliability level of about .87 .

\subsection{Data Analysis}

Primary data were analyzed by Chi-square statistical method using the statistical package for the social sciences (SPSS) and presented in tables.

\section{PRESENTATION OF STATISTICAL RESULTS}

[DataSetO]

Chi - Square Tests 
Table 1: Frequencies

\begin{tabular}{|l|l|l|l|}
\hline & Observed N & Expected N & Residual \\
\hline 8.00 & 8 & 70.4 & -62.4 \\
\hline 23.00 & 23 & 70.4 & -47.4 \\
\hline 40.00 & 40 & 70.4 & -30.4 \\
\hline 93.00 & 93 & 70.4 & 22.6 \\
\hline 188.00 & 188 & 70.4 & 117.6 \\
\hline Total & 352 & & \\
\hline
\end{tabular}

Table 2: Test Statistics

\begin{tabular}{|l|l|}
\hline & VAR00003 \\
\hline Chi-Squares & 304.051 \\
\hline df & 4 \\
\hline Asymp. Sig & .000 \\
\hline
\end{tabular}

a. 0 cells $(.0 \%)$ have expected frequencies less than 5 . The minimum expected cell frequency is 70.4

\subsection{Interpretation of results.}

From the schematic model in Figure 1, it was observed that the relevant factors of emotional intelligence have virtual correspondence with organizational competitiveness (CLEARY, 1992). And from the Test Statistics, in table 2 it was noted that the calculated X2value of approximately 304 was significantly greater than the table value of approximately 9 , at 0.05 level of significance with 4 degrees of freedom.

By this statistical result it was found that emotional intelligence has significant positive relationship with organizational competitiveness. This result supports the results of Cherniss (2001) and Cherniss and Goleman (2001) that also found positive correspondence between emotional intelligence and organizational effectiveness as well as significant positive relationship between emotional intelligence and workplace success.

\subsection{Discussion}

Several studies have found that emotional intelligence can have a significant impact on various areas of human endeavour. Palmer, et al, (2001) found that higher emotional intelligence is a predictor of life satisfaction. Also that people higher in emotional intelligence are also more likely to exhibit healthier psychological adaption.

Performance measures of emotional intelligence illustrate that higher levels of emotional intelligence are associated with an increased likelihood of good health and appearance, positive interactions with friends, customers and family members. Other researchers find that high emotional intelligence is associated with increased positive 
interpersonal relationships among children, adolescents and adults (RICE, 1999, RUBIN, 1999).

Again, negative relationships have likewise been identified between emotional intelligence and problem behaviour (Mayer, et al, 2000). Mandell and Pherwani (2003) report a high positive correlation between emotional intelligence and transformational leadership. The transformational leader stimulates interest among colleagues, inspires a different outlook on the work, generates an awareness of the goals of the organization, develops others to higher levels of ability and motivates others to consider the interests of the group over their own interests (BASS; AVOLIO, 1994).

Emotional intelligence helps organizational leaders to develop a vision for their organizations, motivates subordinates to commit to the vision and energize them to enthusiastically work to achieve this vision. Moreover, emotional intelligence may enable leaders to develop a significant identity for their organizations and instill high levels of trust and co-operation throughout the organization while maintaining the flexibility needed to respond to changing conditions. Individual and group emotional intelligence contribute to organizational effectiveness and competitiveness.

According to Cherniss (2001) emotional intelligence emerges primarily through relationships. At the same time emotional intelligence affects the quality of relationships. Relationship can help people become more emotionally intelligent even when they are not set up for that purpose. This suggests that ultimately any attempts to improve emotional intelligence in organizations will depend on relationships or human resource policies which affect emotional intelligence through their effect on relationships among individuals and groups in the organization. In a model he illustrates three organizational factors that are interrelated.

Each of these factors influences emotional intelligence through its impact on relationships, and each factor influence the other two. The model showed how the emotional intelligence of organizational leadership influences organizational effectiveness which is a requisite for organizational competitiveness. Likewise the schematic model, showed the virtual correspondence between individual emotional intelligence, group emotional intelligence, leadership and organizational competitiveness. 
DOI: 10.14807/ijmp.v7i3.427

The model relied on emotional intelligence as the index of emotional competencies that produce organizational competitiveness. Organizational competitiveness requires the maximization of group's emotional intelligence, the synergistic interaction of every person. This suggests that the correct measure of excellence involves the capabilities of the human mind and the competencies critical to workplace success.

McClelland (1993) posits that a set of specific competencies, including empathy, self-discipline, and initiative provide a distinction among the most successful from those who are merely sound enough to keep their jobs. According to him a competence in this tradition is a personal trait or set of habits that lead to more effective or superior job performance, in other words, an ability that adds clear economic value to the efforts of a person on the job that may lead to organizational competitiveness (MCCLELLAND, 1973).

\subsection{Recommendations}

i) Organizations should encourage the development of healthy relationships so as to encourage effectiveness and competitiveness.

ii) Managers and workers as the heart and soul of organizations should be properly motivated to enable them perform to their fullest potentials to enhance organizational competitiveness.

iii) Organizations need more of transformational leaders who can provide above average incremental changes for the growth and competitiveness of their organizations.

iv) Organizations should have a tradition of retaining experienced workers who might have a high dose of emotional intelligence needed for organizational competitiveness.

v) Organizations should pay attention to training of managers and workers so as to develop latent competencies. This is unique for organizational competitiveness because competence comes in multiples. Organizations and individuals interface in ways that require a multitude of emotional intelligence abilities each most effective when used in conjunction with others in synergistic clusters. 


\subsection{Scope for further research}

Further research should examine the relationship between emotional intelligence and organizational policy. This is necessary to help in formulating policies that would help in organizational stability.

\section{CONCLUSION}

The Science of emotional intelligence continues to attract attention in respect of organizational prosperity, effectiveness and change since it was brought to its academic zenith by Goleman (1995). Earlier researchers like Groves (2006) found a positive relationship between emotional intelligence and organizational change, while Bass and Avolio (1994) also reported a positive relationship between emotional intelligence, among others.

In furtherance of research in this domain, and through schematic and statistical analyses; this study found a strong positive correlation between emotional intelligence and organizational competitiveness. Competitiveness is based on strategy, a plan for achieving organizational goals through tactics, or methods and actions taken to accomplish strategies. This fresh contribution in a great measure; supports the works of Cherniss (2001) and Mandell and Pherwani (2003). This is the interest of the study.

\section{REFERENCES}

AMERICAN SOCIETY FOR TRAINING AND DEVELOPMENT (1997)

Benchmarking from member-to-member. Alexandria Virginia

BAR-ON, R. (1997) The Bar-On Emotional Quotient Inventory (EQ-i): Technical Manual, Toronto Canada: Multi-Health Systems.

BAR-ON, R. (2004) The Bar-On Emotional Quotient Inventory (EQ-i): Rationale, Description and Summary of Psychometric Properties. In G. GEHER (Ed) Measuring Emotional Intelligence. Common Ground and Controversy Hauppauge, NY Nova Science Publishers, p. $111-42$.

BAR-ON, R. (2006) The Bar-On Model of Emotional Social Intelligence (ESI) Priscothema, n. 18, Supl 13-25.

BASS, B. M.; AVOLIO, B. J. (1994) Improving Organizational Effectiveness through transformational leadership. Thousand Oaks, CA: Sage.

BLAKE, R. R.; MOUTON, J. S. (1964) The Managerial grid. Houston: Gulf Publishers. 
BOUNDS, G.; DOBBINS, H.; OSCAR, S. F. (1995) Management. A Total Quality Perspective Cincinnati, South-Western Publishing.

CHASE, R. B.; AGUILLANO, N. J.; JACOBS, F. R. (2001). Operations

Management: A Competitive Advantage $9^{\text {th }}$ edition, New York McGraw-Hill Irwin.

CHERNISS, C. (2001) Emotional Intelligence and Organizational Effectiveness. In CHERNISS, C.; GOLEMAN, D. (Eds) The Emotionally Intelligent Workplace San Fransisco, Jossey, Bass, pp: 3-12.

CHERNISS, C.; GOLEMAN, D (2001) The Emotionally Intelligent Workplace. Jossey-Bass San Francisco.

CLEARY, R. (1992) Models as effective research tools. In D. M. CAVANASH \& G. M RODWELL, (Eds) Dialogues in educational research, Darwin, NT: William Michael Press.

DRUCKER, P. F. (1998) Peter Drucker on the Profession of Management, Boston: A Harvard Business, Review Book.

DYE, T. R. (1992) Understanding Public Policy Englewood, Cliff, N. J Prentice Hall.

Fineman, G. (1997) Emotion and Management Learning. Management Learning, v. 28, n. 1, p. 13-25.

GARDNER, L.; STOUGH, C. (2002) Examining the relationship between leadership and emotional intelligence in senior level managers. Leadership and Organization Development Journal, n. 23, p. 68-98.

GERARD, G.; TEURFS, L. (1995) Dialogue and Organizational Transformation. In K. CORDZ (Eds) Continuity Building. Renewing Spirit and Learning in Business pp: 143 - 153, San Francisco. New Leaders Press.

GEORGE, JR. C. (1972) The History of Management Thought: $2^{\text {nd }}$ edition Prentice-Hall, Inc. Englewood Cliffs, New Jersey.

GOLEMAN, D. (1995) Emotional Intelligence Why It Can Matter More Than IQ. New York, Bantam Books.

GOLEMAN, D. (1998) Working with Emotional Intelligence, New York, Bantam Books.

GOLEMAN, D.; BOYATZIS, R.; MCKEE, A. (2002) Primal Leadership: Realizing the Power of Emotional Intelligence. Boston Harvard Business School Press.

GROVES, K. S. (2005) Linking leaders skills, follower attitudes, and contextual variables via an integrated model of charismatic leadership. Journal of Management, n. 31, p. 255-277.

GROVES, K. S. (2006) Leader Emotional Expressivity, Visionary Leadership, and Organizational Change. Leadership and Organization. Development Journal, n. 27, p. 566-583.

HAY/MCBER (2000) Research into Teacher effectiveness. A Model of Teacher Effectiveness, Report by Hay/McBer to the Department of Education and Employment. Available at http://www.dfee.gov.uk/teacheringreforms/mcber/ 
HERZBERG, F. (1974) Work and the Nature of Man. London. Crosby, Lockwood and Staples.

JAWORSKI, J. (1996) Synchronicity: The inner path of leadership. San Francisco. Beret - Koehler Publications.

KEEVES, J. P. (1997) Models and Model Building. In J.P Keeves (Ed.) Education Research.

KLUEMPER, D. H. (2008) Trait Emotional Intelligence. The Impact of Core-Self Evaluations and Social Desirability. Personality and Individual Differences, v. 44, n. 6, p. 1402-1412 LAK.

MANDELL, B.; PHERWANI, S. (2003) Relationship between emotional intelligence and transformational leadership style: A gender Comparison. Journal of Business and Psychology, n. 17, p. 387-404.

MASLOW, A. H. (1954) Motivation and Personality. New York, Harper.

MAYER, J. D.; SALOVEY, P. (1997) What is Emotional Intelligence? In P. SALOVEY AND D. J SHIYTER (Eds.) Emotional Development, and Emotional Intelligence: Educational Implications. New York, Basic Books, pp: 3-32.

MAYER, J. D.; SALOVEY, P.; CARUSO, D. R. (2000) Models of Emotional Intelligence. In R. J STERNBERG (Ed) Handbook of human intelligence. New York, Cambridge University Press, p. 396-420.

MAYER, J. D.; SALOVEY, P.; CARUSO, D. R. (2002) The Mayer, Salovey Caruso, Emotional Intelligence Test (MSCEIT) Users. Manual, Toronto: Multi-Health Systems.

MCCLELLAND D. C. (1973) Testing of competence rather than intelligence.

American Psychologist, v. 28, n. 1, p. 1-14

MCCLELLAND D. C. (1993) Intelligence is not the best predictor of job performance. Current Directions in Psychological Research, n. 2, p. 5-8

MCGREGOR, D. (1960) The Human Side of Enterprise. New York, McGraw-Hill. MCLEOD, R. J (1997) The Management of Change. Business Studies Review, v. 3, n. 2, p. 1-7.

MIKOLAJEZAK, LUMINET, LEZOY; ROY (2007) Psychometric Properties of the Trait Emotional Intelligence Questionnaire. Factor Structure, Reliability, Construct and Incremental Validity in a French-Speaking Population. Journal of Personality Assessment, v. 88, n. 3, p. 338-353.

MORECROFT, D. W.; STARMAN, J. D. (1994) Modeling for Learning Organizations. Portland, Oregon, Productivity Press.

NUNNALLY, J. C.; BERNSTEIN, I. H. (1994) Psychometric Theory, $3^{\text {rd }}$ Edition, New York, McGraw-Hill.

PALMER, B. R.; STOUGH, C. (2000) Swineburne University Emotional Intelligence Test (Workplace SUEIT). Interim Technical Manual (Version 2)

PETRIDES, K. V.; FURNHAM, A. (2000) On the Dimensional Structure of emotional intelligence, Personality and Individual Differences, v. 29,n. 2, p. 313-320. 
PETRIDES, K. V.; FURNHAM, A. (2001) Trait Emotional Intelligence: Psychometric Investigation with reference to established trait taxonomies. European Journal of Personality, v. 15, n. 6, p. 423-448.

PFEIFER, S. I. (2001) Emotional Intelligence: Popular but elusive construct. Roeper Review, v. 23, n. 3, p. 138-143.

RICE, V. H. (2000) Handbook of stress coping and health. Thousand Oaks, CA, Sage

RUBIN D. C. (1999) Remembering your Past: Studies in autobiographical memory, New York, Cambridge University Press.

RUBIN, R. S.; MUNZ D. C.; BOMMER W. H. (2005). Leading from within. The effects of emotion, recognition and personality on transformational leadership. Academy of Management Journal, n. 48, p. 845-858

SAARNI, C. (1988) Emotional Competence: How emotions and relations became integrated. In R. A. THOMPSON (ed.) Nebraska Symposium on Motivation, v. 36

SALONA, P.; SLUYTER D. J. (1997) Emotional development and emotional intelligence. New York, Basic Books

SCHUTTE, N. S.; MALOUFF, J. M.; HALL, L. E.; HAGGERTY, D. J.; COOPER, J. T.; GOLDEN, C. J.; ONCE DORNHEIM, L. (1998) Development and validation of a measure of Emotional intelligence, Personality and Individual Differences, n. 25, p. $167-177$

SENGE, P. (1990) The Fifth Discipline: The Art and Practice of Learning Organizations, New York, Double day/Currency

SJOBERG, L. (2000) Emotional Intelligence: Psychometric Analysis. European Psychologist, n. 6, p. 79-95

SPECTOR P. (2005) Introduction Emotional Intelligence. Journal or organizational Behaviour

SPENCER, JR., L. M.; SPENCER, S. M. (1993) Competence at Work: Models for Superior Performance. New York, John Willey and Sons

STERNBERG, R. J. (1998) Successful Intelligence: How practical and creative intelligence determine success in life. New York, Plume

STERNBERG, R. J.; WAGNER, R. K., (1986) Practical Intelligence Nature and Origins of competence in the everyday world. Cambridge: Cambridge University Press

STERNBERG, R. (1996) Successful Intelligence. New York, Simon \& Schuster.

STERNBERG, R. J. (1998) Successful Intelligence: How practical and creative intelligence determine success in life. New York, Plume

STEVENSON, W. J. (2002) Operations Management. $7^{\text {th }}$ edition; New York, McGraw-Hill, Irwin.

WEISS, R. P. (2000) Promoting Emotional Intelligence in organizations: making training in emotional intelligence effective. American Society of Training and Development. 
INDEPENDENT JOURNAL OF MANAGEMENT \& PRODUCTION (IJM\&P)

http://www.ijmp.jor.br

v. 7, n. 3, July - September 2016

ISSN: 2236-269X

DOI: 10.14807/ijmp.v7i3.427

WU, W.; TIU, Y.; SONG, L. J.; LIU, J. (2006) Effects of Organizational Leadership on employee commitment: The moderating role of emotional intelligence. Journal of Psychology in Chinese Societies, p. 283-326 